Фармацевтичний менеджмент, маркетинг та логістика

Pharmaceutical management, marketing and logistics

Рекомендована д. фармац. наук, проф. В. В. Трохимчуком

УДК 615.276:339.13.021

\title{
МАРКЕТИНГОВІ ДОСЛІДЖЕННЯ ФАРМАЦЕВТИЧНОГО РИНКУ НЕСТЕРОЇДНИХ ПРОТИЗАПАЛЬНИХ ЛІКАРСЬКИХ ЗАСОБІВ ВІННИЧЧИНИ
}

\author{
○В. П. Бобрук, О. Д. Благун \\ Вінницький національний медичний університет імені М. І. Пирогова
}

\begin{abstract}
Резюме: за результатами дослідження асортиментної структури нестероїдних протизапальних лікарських препаратів, представлених на фармацевтичному ринку Вінниччини, встановлено, що у його забезпеченні більш значну частку становлять іноземні фірми-виробники $(70,1 \%)$ порівняно із вітчизняними (29,9 \%). Домінуючими на фармацевтичному ринку є похідні фенілпропіонової (29,90 \%) та фенілоцтової (26,8 \%) кислот, дещо менше у сегменті ринку представлені похідні оксикамів (16,50 \%), що підтверджується аналізом даних коефіцієнта напруженості: найвища конкуренція спостерігається серед фірм, які випускають препарати похідних фенілоцтової, фенілпропіонової кислот і оксикамів. В даній роботі встановлено рейтинговий ряд НПЗЗ препаратів-аналогів за продажем у межах кожної хімічної групи.
\end{abstract}

Ключові слова: маркетинг, асортиментна структура, нестероїдні протизапальні лікарські препарати.

Вступ. Значення нестероїдних протизапальних лікарських засобів (НПЗ3) у сучасному житті людини важко переоцінити, оскільки вони належать до числа найбільш поширених лікарських засобів (л/з) [1]. 3 кінця XX століття і дотепер відмічається тенденція до збільшення вживання НПЗЗ у 2-3 рази кожні 10 років $[1,2]$. Кожний третій мешканець планети використовує НПЗ3. Широке коло гострих і хронічних захворювань, що супроводжуються запальним процесом і болем, при лікуванні котрих використовують нестероїдні протизапальні лікарські засоби, зумовлює актуальність своєчасного і оптимального забезпечення хворих ефективними л/з із хорошим профілем безпечності. У той же час якість і повнота надання належної фармацевтичної допомоги населенню значною мірою спирається на уміння правильно сформувати асортимент лікарських препаратів. Тому як для лікарів, так і для працівників аптечних закладів необхідна своєчасна інформація щодо препаратів, представлених на фармацевтичному ринку [3].

Метою та завданням даної роботи було проведення маркетингового аналізу асортименту лікарських засобів протизапальної дії вітчизняного та іноземного виробництва і визначення їх конкурентоспроможності.

Методи дослідження. Аналіз асортиментної структури нестероїдних протизапальних лікарських препаратів здійснювали на основі інформації прайс-листів сервісної компанії «БаДМ» у період червень 2013 - червень 2014 рр. у зв'язку з максимальним асортиментом досліджуваних лікарських засобів, представ- лених на ринку Вінничини саме цією сервісною фармкомпанією.

Для визначення ступеня напруженості між виробниками препаратів-аналогів розрахували коефіцієнт напруженості (Kvi) за формулою:

$\mathrm{Kvi}=\mathrm{n}-1 / \mathrm{n}$,

де $\mathrm{n}$ - кількість усіх конкурентних аналогів фірм [4].

Аналіз здійснювали на основі даних звітності продажів компанії «БаДМ» за вказаний період.

Результати й обговорення. За даними прайс-листів сервісної компанії «БаДМ» встановлено, що у період червня 2013 - червня 2014 рр. на регіональному фармацевтичному ринку Вінниччини в обігу знаходиться 128 лікарських форм НПЗЗ за різними МНH.

За результатами дослідження асортиментної структури НПЗЗ встановлено, що лише 29,9 \% таких л/з виробляють на території України (рис. 1). Серед іноземних країн-постачальників лідируючі позиції займають виробники Німеччини $(18,10 \%)$ та Індії $(15,48 \%)$, дещо менше на фармацевтичному ринку представлені виробники Словенії (14,91\%) та Польщі (12,89 \%), 6,32 \% припадає на виробників Італії, продукція цих країн представлена 6-21 препаратом; 2,40 \% припадає на інших іноземних виробників, продукція котрих представлена 1-4 препаратами (рис. 1).

У виробництві НПЗЗ українські виробники представлені: ТОВ «Фармацевтична компанія «Здоров'я» (м. Харків), ВАТ «Фармак» (м. Київ), ПАТ «Київський вітамінний завод» (м. Київ), ВАТ «Київмедпрепарат» (м. Київ), АТ «Галичфарм» (м. Львів), ТОВ «КУСУМ ФАРМ» (м. Суми).

ISSN 2312-0967. Фармацевтичний часопис. 2015. № 1 
Фармацевтичний менеджмент, маркетинг та логістика

Pharmaceutical management, marketing and logistics

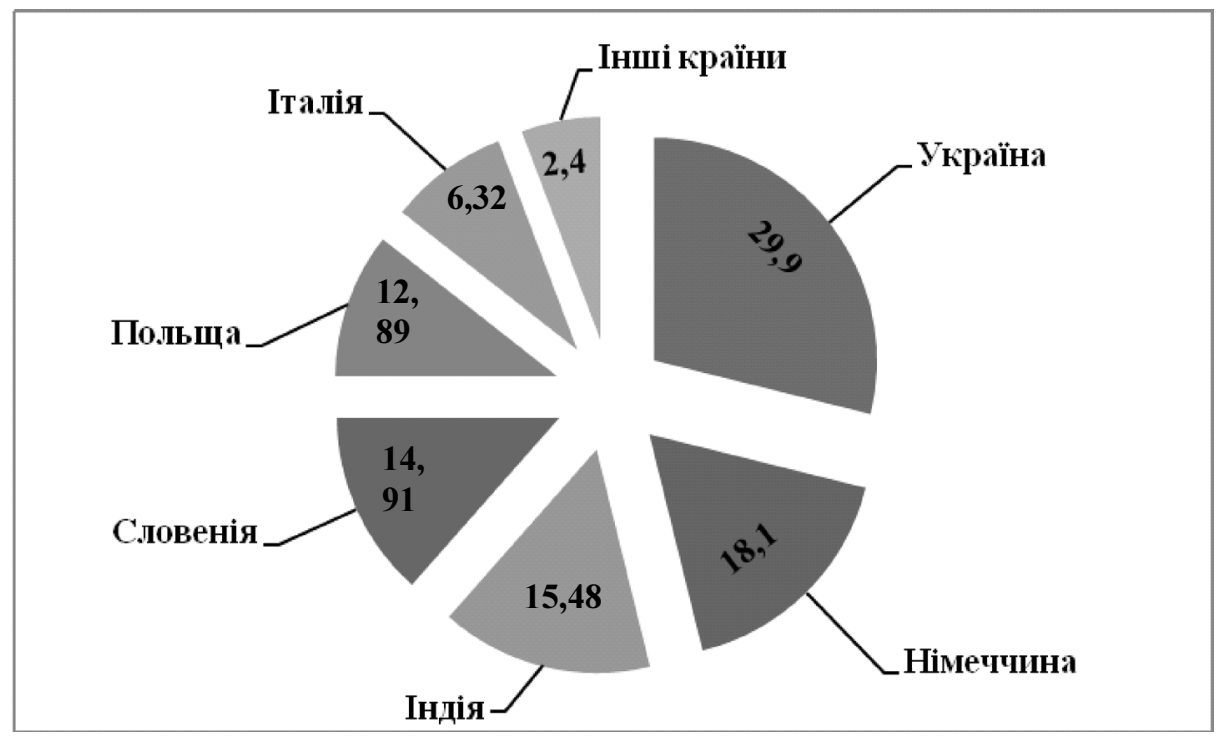

Рис. 1. Структура ринку лікарських засобів групи НПЗЗ залежно від країни-виробника.

Фармацевтичний ринок іноземних виробників представлений: БЕРЛІН-ХЕМІ АГ (МЕНАРІНІ ГРУП), Байєр Фарма АГ, Байєр Біттерфельд ГмбХ (Німеччина), Пфайзер Фармасьютікалз Ел. Ел.Сі./Пфайзер Менюфекчуринг Дойчленд ГмбХ (США/Німеччина); Мепро Фармасютікалз Пріват Лімітед, КУСУМ ХЕЛТХКЕР ПВТ. ЛТД, Маклеодс Фармасьютикалс Лімітед (Індія); КРКА, д.д., Ново место (Словенія); «ПОЛЬФАРМА» С.А. (Польща); Новартіс Фарма С.п.А., А. Менаріні Мануфактурінг, Логістікс енд Сервісес С.р.Л. (Італія).

Серед НПЗЗ найбільш популярними та запитуваними препаратами, як і раніше, залишаються похідні саліцилової (39%) та фенілоцтової кислот (35 \%), значну частку серед НПЗ3 становлять похідні фенілпропіонової кислоти (16\%), найменшу частку становлять похідні оксикамів, ідолової кислоти та інших хімічних груп (загалом 11 \%) (рис. 2).

Виявлене співвідношення похідних різних хімічних груп у структурі ринку лікарських засобів групи НПЗЗ зумовлене зацікавленістю практичної медицини не лише у вираженому терапевтичному ефекті препаратів зі швидким купіруванням симптомів запалення, стабільним цілодобовим лікувальним ефектом, а й в оптимальному співвідношенні користь/ризик стосовно їх гастроінтестинальної токсичності та більш високої

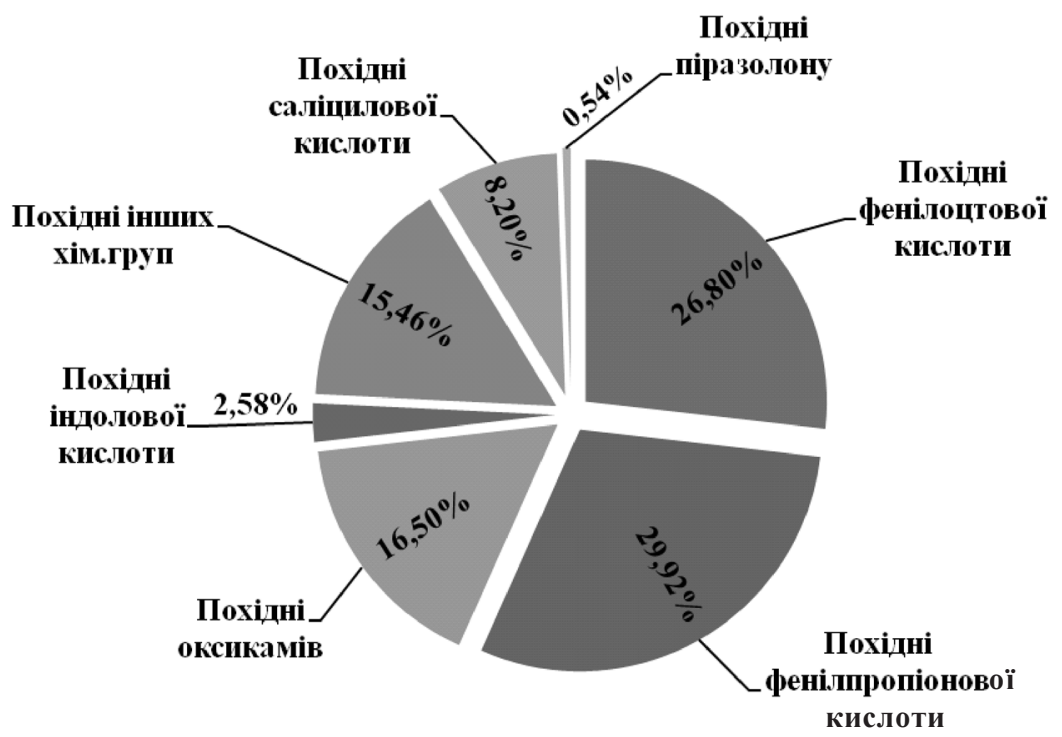

Рис. 2. Структура ринку лікарських засобів групи НПЗЗ відповідно до хімічних груп.

ISSN 2312-0967. Pharmaceutical review. 2015. № 1 
Фармацевтичний менеджмент, маркетинг та логістика Pharmaceutical management, marketing and logistics

кардіоваскулярної небезпеки, різномаїтті форм випуску та зручною схемою прийому препаратів.

Аналіз номенклатури продемонстрував, що НПЗЗ випускаються у різних лікарських формах (рис. 3).

Традиційно, частка твердих л/з, завдяки зручності їх застосування як в амбулаторних умовах, так і в стаціонарі, є домінуючою (65,95 \%). Серед інших форм л/з переважають розчини для ін'єкцій (14,16 \%), що пов'язано з їх широким використанням в умовах стаціонарного лікування та форми у вигляді гелю $(7,01 \%)$, що зумовлено зростанням частки осіб похилого віку і, як наслідок, зростанням поширення захворювань опорно-рухового апарату, особливо таких, що супроводжуються суглобовим синдромом [5, 6].

Далі ми проаналізували ступінь напруженості між виробниками препаратів-аналогів. Зазначимо, що даний показник широко використовують при маркетингових дослідженнях національного ринку лікарських засобів різних фармакологічних груп [4, 7, 8, 9].

За результатами визначення ступеня напруженості між виробниками препаратів-аналогів встановлено, що найвища конкуренція спостерігається серед фірм, які випускають препарати похідних фенілоцтової, фенілпропіонової кислот і оксикамів. Висока конкуренція спостерігається між фірмами, що випускають препарати, які входять до різних хімічних груп за МНН: диклофенаку $(0,980)$, ібупрофену $(0,969)$, мелоксикаму $(0,964)$, ацетилсаліцилової кислоти $(0,937)$, німесуліду $(0,923)$, кетопрофену $(0,916)$ (табл. 1$)$.

Несуттєво поступаються їм у конкуренції фірмивиробники л/з за МНН: індометацину $(0,800)$, дексібупрофену $(0,750)$, напроксену $(0,833)$, піроксикаму $(0,750)$ і целекоксибу $(0,750)$ (табл. 1$)$.

Наведемо приклад розрахунку коефіцієнта напруженості для похідних ацетилсаліцилової кисло-
Таблиця 1. Показники коефіцієнта напруженості між виробниками препаратів-аналогів за МНH нестероїдних протизапальних лікарських засобів

\begin{tabular}{|c|c|}
\hline Найменування л/з за МНН & $\begin{array}{c}\text { Коефіцієнт } \\
\text { напруженості }\end{array}$ \\
\hline \multicolumn{2}{|c|}{ Похідні саліцилової кислоти } \\
\hline $\begin{array}{l}\text { Ацетилсаліцилова кислота } \\
\text { (Аспірин) }\end{array}$ & 0,937 \\
\hline \multicolumn{2}{|c|}{ Похідні піразолону } \\
\hline Фенілбутазон & 0,0 \\
\hline \multicolumn{2}{|c|}{ Похідні індолової кислоти } \\
\hline Індометацин & 0,800 \\
\hline \multicolumn{2}{|c|}{ Похідні фенілоцтової кислоти } \\
\hline Диклофенак & 0,980 \\
\hline \multicolumn{2}{|c|}{ Похідні фенілпропіонової кислоти } \\
\hline Дексібупрофен & 0,750 \\
\hline Ібупрофен & 0,969 \\
\hline Декскетопрофен & 0,00 \\
\hline Кетопрофен & 0,916 \\
\hline Напроксен & 0,833 \\
\hline Набуметон & 0,500 \\
\hline \multicolumn{2}{|c|}{ Похідні оксикамів } \\
\hline Піроксикам & 0,750 \\
\hline Мелоксикам & 0,964 \\
\hline \multicolumn{2}{|c|}{ Похідні інших груп } \\
\hline Німесулід & 0,923 \\
\hline Целекоксиб & 0,750 \\
\hline Лорноксикам & 1,000 \\
\hline Рофекоксиб & 0,500 \\
\hline Ацеклофенак & 0,660 \\
\hline Діацереїн & 0,666 \\
\hline
\end{tabular}

ти: кількість лікарських засобів, зареєстрованих у Державному реєстрі - 24, кількість в прайсі компанії БаДМ - 16 (українського виробника - 7, іноземного виробника - 9). Тому Kvi = 16-1/15 = 0,937.

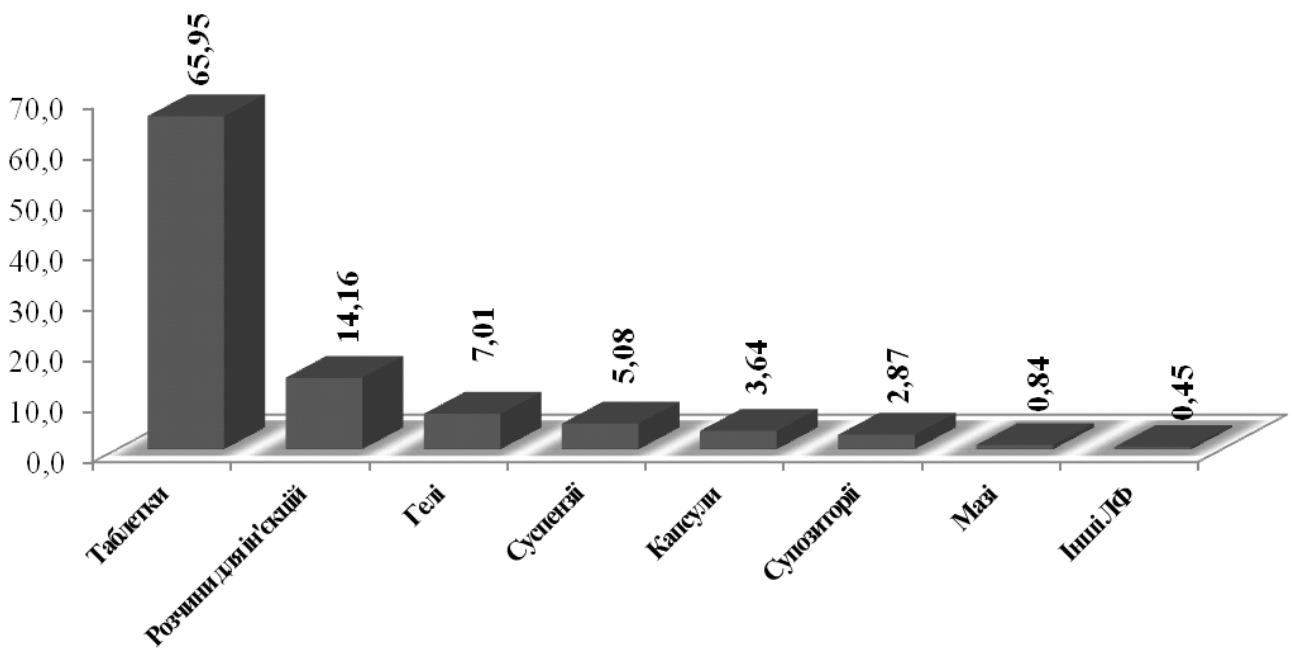

Рис. 3. Асортимент лікарських засобів групи НПЗЗ залежно від виду лікарської форми.

ISSN 2312-0967. Фармацевтичний часопис. 2015. № 1 
Фармацевтичний менеджмент, маркетинг та логістика

Pharmaceutical management, marketing and logistics

Висновки. 1. Проведені маркетингові дослідження фармацевтичного ринку нестероїдних протизапальних лікарських засобів свідчать про їх досить широкий асортимент. У забезпеченні досліджуваного сегмента ринку значну частку становлять іноземні фірми-виробники, порівняно із вітчизняними, що створює перспективу освоєння їх виробництва на території України.

\section{Література}

1. Трухан Д. И. Выбор нестероидного противовоспалительного препарата с позиций профилактики НПВПгастропатии и лекарственной безопасности / Д. И. Трухан // Consilium Medicum. - 2014. - T. 16, № 8. C. 14-19.

2. Насонова В. А. Рациональная фармакотерапия ревматических заболеваний: рук. для практикующих врачей; под общ. ред. В. А. Насоновой, Е. Л. Насонова. М. : Литтерра 2007. - 434 с.

3. Прокопенко И. П. Маркетинговое изучение современного фармацевтического рынка диуретических средств / И. П. Прокопенко, Г. Н. Шестаков // Фармация. - 2010. - № 1. - С. 23-26.

4. Белошапка В. А. Стратегическое управление и маркетинг в практике фармацевтических фирм / В. А. Белошапка, Г. В. Загорий, В. А. Усенко. - К. : Триумф, 2001. - С. 251-274

5. Коваленко В.Н.Оптимальный выбор нестероидных противовоспалительных препаратов: баланс эффективности и безопасности / В. Н. Коваленко, Н. М. Шуба, В. А. Радченко // Здоровье Украины. 2005. - № 20 (129). - С. 38-39.
2. Найвища конкуренція спостерігається серед фірм, які випускають препарати похідних фенілоцтової, фенілпропіонової кислот і оксикамів.

Результати маркетингових досліджень сучасного фармацевтичного ринку НПЗЗ можуть бути використані при формуванні оптимального і раціонального асортименту НПЗЗ в аптеках, що сприятиме кращій рентабельності роздрібної аптечної мережі.

6. Ревматология. Национальное руководство / под ред. Е. Л. Насонова. - М. : ГЭОТАР-Медиа, 2008. $720 \mathrm{c}$.

7. Маркетингові дослідження регіонального ринку лікарських засобів для лікування лейкозів у дітей (на прикладі Запорізької області) / Т. П. Зарічна, І. Р. Авраменко, І. В. Бушуєва [та ін. ] // Запорожский медицинский журнал. - 2012. - № 4 (73). - С. 15-17.

8. Зарічна Т. П. Маркетингові дослідження національного ринку лікарських засобів кардіологічної групи / Т. П. Зарічна, О. С. Бідненко // Здобутки та перспективи управління фармацевтичною системою : зб. матеріалів наук.-практ. конф. 3 міжнародною участю, присвячена 50-літтю створення кафедрим ОЕФ Львівського національного медичного університету імені Данила Галицького, (Львів, 25-26 вересня 2014p.). - Львів : Вид-во «Растр-7», 2014. - С. 49-50. 9. Маркетингові дослідження національного ринку лікарських засобів муколітичної дії (на прикладі Донецької області) / Т. П. Зарічна, О. Ю. Фабрій, Т. С. Райкова // Соціальна фармація: стан, проблеми та перспективи : матеріали міжнар. наук.-практ. інтернет-конф., (Харків, 1720 березня 2014p.). - Харків, 2014. - С. 247-253.

\title{
МАРКЕТИНГОВЫЕ ИССЛЕДОВАНИЯ ФАРМАЦЕВТИЧЕСКОГО РЫНКА НЕСТЕРОИДНЫХ ПРОТИВОВОСПАЛИТЕЛЬНЫХ ЛЕКАРСТВЕННЫХ СРЕДСТВ ВИННИЧЧИНЫ
}

\author{
В. П. Бобрук, О. Д. Благун \\ Винницкий национальный медицинский университет имени Н. И. Пирогова
}

Резюме: по результатам исследования ассортиментной структуры нестероидных противовоспалительных лекарственных препаратов, представленных на отечественном фармацевтическом рынке Винниччины, выявлено, что в его обеспечении более значительную долю составляют иностранные фирмы-производители (70,1\%) сравнительно с отечественными (29,9%). Доминирующими на фармацевтическом рынке являются производные фенилпропионовой $(29,9 \%)$ и фенилуксусной $(26,8$ \%) кислот, несколько меньше в сегменте этого рынка представлены производные оксикамов (16,50 \%), что подтверждается анализом данных коэфициента напряженности: наиболее высокая конкуренция наблюдается среди фирм, которые выпускают препараты производных фенилуксусной, фенилпропионовой кислот и оксикамов. В данной работе определен рейтинговый ряд НПВС препаратов-аналогов по МНH по продажах в каждой химической группе.

Ключевые слова: маркетинг, ассортиментная структура, противовоспалительные лекарственные препараты.

ISSN 2312-0967. Pharmaceutical review. 2015. № 1 


\section{MARKETING RESEARCHES OF THE PHARMACEUTICAL MARKET OF NONSTEROID ANTI- INFLAMMATORY MEDICINES IN VINNYTSIA REGION}

\section{P. Bobruk, O. D. Blagun}

Vinnytsia National Medical University of M. I. Pyrohov

Summary: by results of research of assortment structure of the nonsteroid anti-inflammatory medicines (NAIM) presented in the domestic pharmaceutical market of Vinnytsia Region, it is revealed that in his providing more considerable share is made by foreign manufacturing firms $(70.1 \%)$ compared with domestic $(29.9 \%)$. Dominating on pharmaceutical market there are derivatives fenilpropion (29.9\%) and fenilacetic (26.8\%) acids, slightly less in a segment of this market derivatives of oksicam (16.50\%) that is confirmed by the analysis of data of coefficient of intensity are presented: the highest competition is observed among firms which let out preparations of derivatives of fenilacetic, fenilpropion acids and oksicam. In this work a rating number of NAIM of preparations analogs is determined by INN after sales in each chemical group.

Key words: marketing, assortment structure, nonsteroid anti-inflammatory medicines. 